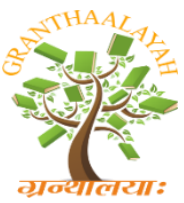

INTERNATIONAL JOURNAL OF RESEARCH GRANTHAALAYAH A knowledge Repository

Science

\title{
PERFORMANCE EVALUATION OF ELITE HOT PEPPER (CAPSICUM ANNUM) VARIETIES FOR YIELD AND YIELD COMPONENTS AT DERASHEA, SOUTH-EASTERN ETHIOPIA
}

\author{
Abraham Alemu ${ }^{1}$, Alemayehu Wodajo ${ }^{2}$, Kanko Chuntal ${ }^{3}$ \\ ${ }^{1,2,3}$ Southern Agricultural Research Institute (SARI) Arbaminch Agricultural Research Center \\ Department of Horticulture, Ethiopia
}

DOI: https://doi.org/10.29121/granthaalayah.v4.i12.2016.2397

\begin{abstract}
Hot peppers are an important cash crop grown in different parts of the world. Hot pepper improvement for processing quality and yield increment being considered as crucial task at most developing country there by to boost the livelihood of producers. Four elite hot pepper varieties such as Mareko fana, Odaharo, Backo local and Halaba local were evaluated for fresh, dried and quality traits at Derashea woreda (Segen Peoples Zone), South-Eastern Ethiopia for two successive years (2013 and 2014). The experiment was laid out under completely randomized block design. The ANOVA result revealed that there were highly significant difference $(\mathrm{P}<0.01)$ among varieties on parameters of fruit length, fruit diameter, number of fruits per plant, fresh fruit yield and dried fruit yield in 2013 cropping season. In contrast, no significant differences $(\mathrm{P}<0.01)$ were observed among varieties in 2014 cropping season on stand count, fruit length, and fruit diameter. Backo local perform best regarding to fresh and dried fruit yield following Odaharo and Mareko fana. The result opens the door for end users to cultivate high yielded variety and create awareness for technology utilization. Hence, producers should have to cultivate Backo local variety for better yield and performance.
\end{abstract}

Keywords: Hot Pepper; Varieties; Adaptation and Yield.

Cite This Article: Abraham Alemu, Alemayehu Wodajo, and Kanko Chuntal. (2016). "PERFORMANCE EVALUATION OF ELITE HOT PEPPER (CAPSICUM ANNUM) VARIETIES FOR YIELD AND YIELD COMPONENTS AT DERASHEA, SOUTH-EASTERN ETHIOPIA." International Journal of Research - Granthaalayah, 4(12), 95-100. https://doi.org/10.29121/granthaalayah.v4.i12.2016.2397

\section{Introduction}

Peppers (Capsicum spp.) belong to Solanaceae family; originated and diversified in south-central South America. Capsicum contains five variously domesticated species such as Capsicum annuum, C. frutescens, C. chinense, C. baccatum and C. pubescens (Rodriguez et al., 2008). 
Peppers are an important cash crop for smallholder farmers in developing countries. Hot pepper (chili) dominates world spice trade, and sweet pepper has become a popular vegetable and cash crop in the tropics for smallholders (Lin et al., 2013). The genus Capsicum is a high value crop used as vegetables and spice in Ethiopia. Since it is a high value crop, it can be used as both domestic and export market. It is important in the local dishes, karia, berbre, processing industries (coloring agent) and export market in the form of oleoresin (red pigment) and ground powder in different forms. It is produced in many parts of the country and serves as cash crop for small scale farmers. Different pepper types such as bell (sweet) pepper which is non-pungent, chili (mitimita) and hot pepper (berbere) which is pungent and dominantly produced in the country (EEPA, 2003).

The world's production area of hot pepper is estimated at four million hectare with an annual average increment of 5\% (Weiss, 2002). In spite of its importance, hot pepper production in Ethiopia is stayed as low with a national average yield of $7.6 \mathrm{t} / \mathrm{ha}$ for green pod whereas it was $1.6 \mathrm{t} / \mathrm{ha}$ for the dry pod (CSA, 2006). The reduction of yield attributed by poor varieties, poor cultural practices, and the prevalence of fungal (blights), bacterial and viral diseases (Fekadu and Dandena, 2006). The present bottleneck of the study site is therefore, limited access of improved varieties, lack of improved agronomic practices and prevalence of pests. Hence, this experiment was aimed to evaluate the performance and adaptability of different improved hot pepper varieties.

\section{Materials and Methods}

\section{Description of Study Site}

The experiment was conducted at Gatto Kebele Farmer training Center (FTC) which is found in Segen People's Zone of Derashea Woreda, South-Eastern Ethiopia. The area has an altitude of 1142 m.a.s.l and $10^{\circ} 30^{\prime} 44^{\prime \prime} \mathrm{N}$ latitude and $29^{\circ} 40^{\prime} 8^{\prime}$ E longitude respectively. The maximum and minimum mean annual temperatures are $27^{\circ} \mathrm{c}$ and $21^{\circ} \mathrm{c}$ respectively. Sandy loam with $\mathrm{pH}$ of 5.4 is the character of the soil where the experiment was conducted. The area receives $1200 \mathrm{~mm}$ average rainfall annually (Southern Agriculture and rural development office 2010; unpublished).

\section{Treatments}

Four pepper varieties (Backo local, Odaharo, Alaba local and Marekofana) were collected from Backo agricultural research center and Alaba local is locally cultivated and used as local check. In the first round experiment (2013) seeds were sown in June, 2013 on a seed bed size of $1.2 \mathrm{mx} 10 \mathrm{~m}$. The seed bed was covered with a dry grass for 10 days. Then, beds were covered by raised shade to protect the seedling from strong sun shine and heavy rainfall until the plants were ready for transplanting. Watering with a fine watering can was done; similar tasks including pertinent agronomic and horticultural practices was done for the next experimental season(2014). Transplanting to the main field was done when the seedlings reached 20 to $25 \mathrm{~cm}$ height and or at 54 days after sown. 


\section{Experimental Design}

The experiment was conducted for two years (2013 and 2014) and four varieties were arranged in a Randomized Complete Block Design (RCBD) with five replications in each experimental year. In both case, the plot size was $2 \mathrm{~m} \times 3 \mathrm{~m}$ (with a total plot size of $6 \mathrm{~m}^{2}$ ). Total amount of plants per row were 10 and total number of plants per plot were 30 . The space between plants and row were $30 \mathrm{~cm}$ and $60 \mathrm{~cm}$ respectively. $200 \mathrm{~kg} / \mathrm{ha}$ DAP as a side dressing during the transplanting operation and out of $100 \mathrm{~kg} / \mathrm{ha}$ UREA, half was applied during the transplanting time and half at 30 days after transplanting (EIAR, 2004). All agronomic practices such as supplemental irrigation, weeding, and protection were implemented.

\section{Data Collected and Analysis}

Data were collected from the two middle rows of 10 plants. Phenological and yield parameters such as, stand count at final harvesting stage, number of fruits per plant, fruit length $(\mathrm{cm})$, fruit diameter $(\mathrm{cm})$, fresh fruit weight and dry weight(quintal per hectare) were collected and analyzed. SAS software version 9.1 was used to analyze the data and Least Significant Difference (LSD) was used to separate significantly different treatment means.

\section{Result and Discussion}

Stand Count (SC): The analysis of variance revealed that the means of stand count between varieties are not differ statistically at $(\mathrm{P}<0.01)$ though the largest plant population was recorded from the variety Mareko fana in 2013 production season and Backolocal in 2014 production season (table 1).

Fruit Length (FL): The result of ANOVA revealed that there is highly significant $(\mathrm{P}<0.01)$ different in fruit length among means of pepper varieties grown in 2013 production season. But, in 2014 there were no significant difference was observed among means of varieties. Therefore, Halaba local variety (table 1 ) leads the remain three varieties by $12.5 \mathrm{~cm}$ average fruit length in 2013 production season while Odaharo bears the shortest fruit length $(8.9 \mathrm{~cm})$. Similarly, Backo local variety leads others by $9.44 \mathrm{~cm}$ fruit length though significant variation was not observed in 2014 production season. The variation recognized in 2013 production season is due to availability of nitrogen and phosphorus in the soil and the nutrient uptake efficiency of variety as compared with the remain three varieties. According to Tesfaw et al. (2013) nitrogen and phosphorus can increase fruit length. This result in agreement with Delelegn (2011) that he determined significant variation of fruit length among varieties. The lack of significant differences among treatment means grown in 2014 cropping season is due to depletion of nitrogen and phosphorus in the soil (Tesfaw et al., 2013). Gonzalez et al. (2001) also reported organic and inorganic fertilizers supplied most of the essential nutrients at growth stage resulting in increase of growth variables including fruit length.

Fruit Diameter (FD): Fruit diameter is one of quality measuring parameter. In this experiment significant variation $(\mathrm{P}<0.01)$ was observed between treatment means. In 2013 production season, Halaba local bears the fruit with highest fruit diameter $(2.5 \mathrm{~cm})$. But, in 2014 production season, varieties was not differ significantly (table 1) in fruit diameter. As indicated in the above 
discussion, depletion of nutrient from the experimental area due to the first experiment (2013) could be the reason in lack of significant differences among treatment means (Tesfaw et al., 2013). In similar manner, Gebremeskel et al. (2015) also reported that the mean value of fruit diameter can significantly affected by varieties that treated alike.

Number of Fruits per Plant (NFPP): There were highly significant differences $(\mathrm{P}<0.01)$ was observed among varieties in fruits per plant in both cropping season. Backo local bears the largest number of fruits per plant 113.2 and 53.6 in 2013 and 2014 cropping season respectively. Halaba local yields the least amount of fruits per plant in both production seasons. This finding is in contrasting with the result of Delelegn (2011) that backo local bears least amount of fruits per plant at Kechema nursery site while Weldel variety bears highest fruits per plant. This may be due to environmental effect (Tesfaw et al., 2013). Fruits per plant was positively correlated with total fruit yield according to Yadeta et al. (2011)'s report.

Table 1: The overall mean values of yield attributed parameters.

\begin{tabular}{lllll|llll}
\hline \multicolumn{4}{c}{ Year } & 2013 & & \multicolumn{4}{c}{2014} \\
Treatments & SC & FL & FD & NFPP & SC & FL & FD & NFPP \\
\hline Marekofana & 23.4 & 9.0 & 2.3 & 60.4 & 28.6 & 8.8 & 1.72 & 38.04 \\
Backo local & 23.6 & 11.1 & 1.7 & 113.2 & 27.4 & 9.44 & 1.78 & 53.56 \\
Odaharo & 21.8 & 8.9 & 1.5 & 87.7 & 25.8 & 8.71 & 1.74 & 37.0 \\
Halaba local & 21.0 & 12.5 & 2.5 & 46.2 & 27.4 & 8.83 & 1.65 & 35.56 \\
LSD & 4.7 & 1.2 & 0.18 & 24.6 & 3.07 & 1.87 & 0.53 & 9.84 \\
CV $(\%)$ & 15.3 & 9.0 & 6.3 & 21.9 & 8.17 & 15.20 & 22.31 & 13.5 \\
P<0.01 & NS & $* *$ & $* *$ & $* *$ & NS & NS & NS & $* *$ \\
\hline
\end{tabular}

- SC, stand count: FL, Fruit length(cm): FD, Fruit diameter(cm): NFPP, Number of fruits per plant

- $\quad$ ** indicates highly significant differences among means, whereas * belongs significant differences among means

- $\quad$ NS, belongs to no significant differences among means

Fresh Fruit Yield (Q/ha): The analysis of variance on fresh fruit yield revealed that there were highly significant differences $(\mathrm{P}<0.01)$ between treatment means (table 2$)$ in both cropping season. In this finding, Backo local variety yields the largest fresh fruit yield $108.92 \mathrm{Q} / \mathrm{ha}$ in 2013 and 105.22 Q/ha in 2014 cropping season respectively. On the other hand, Odaharo yielded the least fresh fruit in both cropping season with the average amount of $50.32 \mathrm{Q} / \mathrm{ha}$ and $35.02 \mathrm{Q} / \mathrm{ha}$ in 2013 and 2014 respectively. This result is inconformity with the finding of Delelegn (2011) that he stated Backo local yielded 1.05 ton/ha while Odaharo recorded 0.79 ton/ha. The yield variation in both cropping season could be due to environmental factors such as soil nutrient depletion, rain pattern and temperature variation. The yield variation among varieties could be due to genetic makeup of varieties and the ability to adapt environmental conditions (Fekadu and Dandena, 2006; Tesfaw et al., 2013). 
Dried Fruit Yield (Q/ha): The analysis of variance on dried fruit yield indicated that there were highly significant difference $(\mathrm{P}<0.01)$ among means of varieties. Backo local also leads the remain varieties with the average values of $16.23 \mathrm{Q} /$ ha and $17.32 \mathrm{Q} / \mathrm{ha}$ in 2013 and 2014 cropping season respectively. But, Odaharo yielded the least dried fruit yield with mean dried yield of 9.6Q/ha and 6.33Q/ha in 2013 and 2014 respectively. According to Yadeta et al.(2011) report there were positive correlation between fresh and dried fruit yield; hence, Baco local provides the highest fresh and dried yield. This finding is agreed with the report of Delelegn (2011) that Backo local bears a total yield of 1.231 ton/ha and 1.17 ton/ha from two experimental sites. The differences among treatment means may be due to varietal differences in nutrient absorption efficiency, especially nitrogen and phosphorus which have enhancing effect on vegetative growth by increasing cell division and elongation thereby create the possibilities of flowering and fruit bearing (ElTohamy et al., 2006). The other decisive factor is also the ability to adapt the existing environmental factors; such as soil type, rain pattern, temperature and light intensity (Gebremeskel et al. 2015).

Table 2: The overall mean values of fresh and dried yield

\begin{tabular}{|c|c|c|c|c|}
\hline \multirow[b]{2}{*}{ Treatments } & \multicolumn{2}{|l|}{ Year $\quad 2013$} & \multicolumn{2}{|c|}{2014} \\
\hline & Fresh yield $(\mathrm{Q} / \mathrm{ha})$ & Dried yield(q/ha) & Fresh yield(Q/ha) & Dried yield(q/ha) \\
\hline Marekofana & 51.5 & 10.01 & 53.33 & 9.55 \\
\hline Backo local & 108.92 & 16.23 & 105.22 & 17.32 \\
\hline Odaharo & 50.31 & 9.26 & 35.02 & 6.33 \\
\hline Halaba local & 62.64 & 12.32 & 42.91 & 8.85 \\
\hline LSD & 27.91 & 3.25 & 25.41 & 0.4307 \\
\hline $\mathrm{CV}$ & 29.63 & 19.73 & 21.3 & 18.9 \\
\hline $\mathrm{P}<0.01$ & $* *$ & $* *$ & $* *$ & $* *$ \\
\hline
\end{tabular}

\section{Conclusion}

Hot pepper is a warm season and high value crop grown well under irrigation and/or rain fed. Since, it is a high value crop, it increase the livelihood of producers mainly small scale farmers. In Ethiopia, small-scale farmers cultivate the crop under irrigation. Increasing production and productivity regarding with this valuable crop is the aim of many producers. Hence, one of the tool is to adapt and popularize an improved varieties to end user. Therefore, this experiment is aimed to evaluate four hot pepper varieties under Derashea (Segen Peoples Zone, South Eastern Ethiopia) condition. Four varieties namely, Mareko fana, Odaharo, Backo local and Halaba local were evaluated for yield and yield related traits. The experiment was conducted in completely randomized Block Design (RCBD) for two successive years and the best performing variety was identified.

Although there were no significant differences between means of varieties in yield related parameters in 2014 cropping season, highly significant variation among means of varieties 
grown in 2013 cropping season was observed. Backo local provide high yield in both cropping year with average fresh and dried fruit yield of 107.07Q/ha and 16.775Q/ha.

It is advisable that producers around the study area should have to use Backo local variety for better performance and high yielding. Improvement activities regarding with disease resistance and early maturing calls further study.

\section{References}

[1] Bozokalfa, K., and Kilic, M. MATHEMATICAL MODELING IN THE ESTIMATION OF PEPPER (Capsicum annuum L.) FRUIT VOLUME; CH. J. Agr. Rese. 70(4) 2010, 626-632.

[2] CSA (Central Statistical Authority of Ethiopia). Agricultural sample survey. 2005/2006(1998 E.C). Report on area and production of crops. Statistical bulletin, vol 1, 2006, 361. Addis Abeba

[3] Delelegn S. EVALUATION OF ELITE HOT PEPPER VARIETIES (Capsicum species) FOR GROWTH, DRY POD YIELD AND QUALITY UNDER JIMMA CONDITION, SOUTH WEST ETHIOPIA, 2011, Jimma, Ethiopia.

[4] EEPA (Ethiopian Export Promotion Agency). Spice Potential and Market Study. Product Development and Market Research Directorate, 2003, Addis Ababa, Ethiopia.

[5] El-Tohamy, A., Ghoname, A. and Abou-Hussein, S. Improvement of pepper growth and productivity in sandy soil by different fertilization treatments under protected cultivation. Journal of applied Science Research, 2: 2006, 8-12.

[6] Fekadu, M. and Dandena, G. Status of Vegetable Crops in Ethiopia. Ugandan Journal of Agriculture, 12(2): 2006, 26-30.

[7] Gonzalez, D.R. Avarez, D. Matheus J, Comparison of three organic fertilizers for the production of sweet corn. Proceedings of the Inter American Society for Tropical Horticulture. 45: 2001, 106-109.

[8] Lin S., Chou, Y. Shieh, H. Ebert, A.W. Kumar, S. Mavlyanova, S. Rouamba, A. Tenkouano A. Sefa, V. A. and Gniffke, P.A. Pepper (Capsicum spp.) Germplasm Dissemination by AVRDC The World Vegetable Center: an Overview and Introspection. CHRONICA HORTICULTURAE 53(3) 2013.

[9] Rodriguez Y., Depestre T. Gomez O. Efficiency of selection in pepper lines (Capsicum annuum), from four sub-populations, in characters of productive interest. Ciencia Investigacion Agraria, 35(1) 2008, 29-40.

[10] Weiss, E.A. World Production and Trade. CABI Publishing, CAB International, 2002, Wallingford, UK.

[11] Yadeta, B. Belew, D. Gebreselassie, W. and Marame F. Genetic association among some atributes of hot pepper( capsicum annum L.) genotypes in West Shoa, Ethiopia; Middile-Est J. Sc. Res. 7(4): 2011, 567-573.

[12] Gebremeskel, H. Abebe, H. Biratu, W. and Jelato, K. Performance evaluation of hot pepper (Capsicum annum L.) varieties for productivity under irrigation at Raya Valley, Northern, Ethiopia; Bas. Res. J. Agr. Sc. Rev. 4(7) 2015, 211-216.

[13] Tesfaw, A. Dechassa, N. and Sadik, K.W.T. Performance of hot pepper (Cupsicum annuum) varieties as influenced by nitrogen and phosphorus fertilizers at Bure, Upper Watershed of the Blue Nile in Northwestern Ethiopia; In. J. Agr. Sc. 3 (8) 2013, 599-608.

\footnotetext{
*Corresponding author.

E-mail address: abraham.alemu@gmail.com
} 